\title{
PENGEMBANGAN PRODUK DAN ANALISIS KELAYAKAN BISNIS ALAT BANTU MENCUCI CLEAN WASHING MC SEBAGAI PENGGANTI SISTEM KERJA MESIN CUCI
}

\author{
Andira dan Dadang Wiratmoko \\ Fakultas Teknik, Jurusan Teknik Indutri, President University \\ e-mail: andira@president.ac.id ; andirataslim@yahoo.com
}

\begin{abstract}
ABSTRAK
Kebutuhan manusia akan sandang yang bersih menjadikan kegiatan mencuci menjadi suatu hal yang tidak dapat dihindarkan. Untuk mempermudah kegiatan pencucian maka diperlukan alat bantu mencuci seperti mesin cuci listrik yang sekarang sering dijumpai. Namun sistem kerja mesin cuci listrik dengan pencucian dengan tangan berbeda yang mengakibatkan berbedanya hasil pencucian. Hal kedua pencucian dengan mesin cuci juga memerlukan biaya tambahan karena penggunaan tenaga listrik. Oleh karena permasalahan tersebut, lalu dilakukan perancangan produk alat bantu mencuci yang sesuai dengan karakteristik keinginan konsumen. Dengan menggunakan analisis "Need-Matrix" untuk menghasilkan produk rancangan yang sesuai dengan kebutuhan konsumen, serta mempertimbangkan factor biaya, listrik, ergonomis, dan nilai effisiensi tempat maka didapatkan rancangan produk alat bantu mencuci yang diberi nama "clean washing mc". Dilakukan juga analisis kelayakan dari aspek marketing, teknis dan finansial. Dengan menghitung nilai variable cost (material, listrik, dan tenaga kerja) dan investasi awal fix cost (gedung, mesin, marketing, dan biaya persiapan awal) serta harga jual ditetapkan Rp. 550.000 dengan nilai margin 25\%. Dari hasil perhitungan didapatkan NPV Rp.1.941.000.000 > 0, nilai IRR 20\% > 7\% dan Pay back 4 tahun +1 bulan. Dari tiga aspek analisis tersebut dapat dinyatakan bahwa bisnis ini layak dijalankan.
\end{abstract}

Kata kunci: Analisis kelayakan, Perancangan produk, alat bantu mencuci, NPV, IRR.

\begin{abstract}
Human needs for clean clothing make washing activities an unavoidable thing. To simplify washing activities, washing tools are needed such as electric washing machines that are now often found. But the work system of the electric washing machine with washing by hand is different which results in different washing results. The second thing is washing with a washing machine also requires additional costs because of the use of electricity. Because of these problems, then the design of washing equipment products is carried out in accordance with the characteristics of consumer desires. By using the "NeedMatrix" analysis to produce a design product that fits the needs of consumers, as well as considering the cost, electricity, ergonomic factors, and the value of place efficiency, it is obtained the design of a washing device product called "clean washing $\mathrm{mc}^{\mathrm{c}}$ A feasibility analysis is also carried out from the marketing, technical and financial aspects. By calculating the value of the variable cost (material, electricity, and labor) and the fixed cost initial investment (building, machinery, marketing, and initial preparation costs) and the selling price set at Rp. 550,000 with a margin value of 25\%. From the calculation results obtained NPV Rp. 1,941,000,000>0, IRR value of 20\%>7\% and Pay back 4 years + 1 month. From the three aspects of the analysis it can be stated that this business is feasible.
\end{abstract}

Keywords: Feasibility analysis, product design, washing aid, NPV, IRR.

\section{PENDAHULUAN}

Kebutuhan manusia akan sandang yang bersih menjadikan kegiatan mencuci menjadi suatu hal yang tidak dapat dihindarkan. Karena telah menjadi rutinitas maka alat bantu mencuci sangat diperlukan untuk mempermudah kerja manusia. Alat bantu mencuci pertama diciptakan di Inggris pada tahun 1767 dengan menggunakan drum kayu yang berputar dan digerakan dengan tenaga manusia. Seiring dengan perkembangannya design alat bantu untuk mencuci terus mengalami perkembangan hingga terbentuklah mesin cuci dengan tenaga listrik seperti saat ini. Namun setiap teknologi baru selalu memiliki kelebihan dan kekuangan tersendiri bagi penggunanya. Untuk menjalankan mesin cuci diperlukan tenaga listrik yang cukup besar sehingga dalam proses operasinya tidak akan lepas dari biaya yang harus ditanggung penggunanya. Selain itu model minimalis mesin cuci juga kurang efektif dalam penempatannya karena tidak dapat disimpan saat tidak digunakan. Mesin cuci juga bisa dikatagorikan peralatan elektronik yang 
cukup mahal sehingga diperlukan biaya yang cukup besar untuk membelinya.

Berdasarkan permasalahan tersebut maka dilakukan survei terhadap 22 responden mengenai kinerja mesin cuci. Kuesioner disusun dengan menggunakan skala likert dimana bobot 1 menyatakan "sangat tidak setuju" dan bobot 5 menyatakan "sangat setuju”. Dari hasil survei tersebut dapat diambil kesimpulan bahwa persepsi masyarakat menunjukan "setuju” bahwa mesin cuci boros listrik dengan rata-rata bobot 4,18, sedangkan faktor yang lain menunjukkan bahwa masyarakat "mendekati setuju" bahwa mesin cuci itu harganya mahal dan hasil cucian kurang bersih dengan rata-rata bobot 3,82. Sedangkan persepsi tentang cuci dengan tangan menyatakan "tidak setuju" bahwa mencuci dengan tangan itu nyaman dengan bobot 2,18. Maka dapat ditarik kesimpulan bahwa kepuasan masyarakat akan produk alat bantu mencuci yang ada (mesin cuci) masih kurang, dan mencuci dengan tangan dirasa kurang nyaman. Hal itu dapat dijadikan indicator bahwa potensi kehadiran produk baru alat bantu mencuci dapat diterima.

\section{METODOLOGI PENELITIAN}

Adapun langlah-langlah penelitian adalah sebagai berikut:

1. Observasi Awal

Langkah awal yang dilakukan pada penelitian ini melakukan observasi melalui pengamatan dari cara kerja mesin cuci dan melakukan interview terhadap sejumlah responden mengenai kinerja dari mesin cuci yang digunakan. Selanjutnya. Dilakukan penyebaran kuesionaer untuk mengetahui pendapat masyarakat.

2. Identifikasi Masalah

Dari hasil observasi yang telah dilakukan maka ditetapkanlah rumusan masalah yang terjadi, setelah itu dilakukan penetapan akan tujuan melakukan penulisan. Agar penulisan tidak keluar ruang lingkup pembahasan maka ditetapkan batasan batasan permasalahan. Seletah itu ditentukan juga asumsi asumsi untuk membantu menyelesaikan permasalahan yang terjadi.
3. Metode Penelitian

Menentukan tahapan untuk berfikir secara sistematis yang akan menggambarkan tahapan-tahapan untuk mengidentifikasi, merumuskan, menganalisa, memecahkan suatu masalah dan sampai pada akhirnya kita dapat menarik suatu kesimpulan dari masalah yang dijadikan objek pengamatan.

4. Identifikasi Masalah

Selanjutnya ditetapkan rumusan masalah yang terjadi, setelah itu dilakukan penetapan akan tujuan melakukan penulisan. Agar penulisan tidak keluar ruang lingkup pembahasan maka ditetapkan batasan batasan permasalahan. Seletah itu ditentukan juga asumsi asumsi untuk membantu menyelesaikan permasalahan.

5. Studi Literatur

Studi literatur ini dilakukan dengan maksud dan tujuan untuk menunjang penelitian dengan melengkapi teori-teori yang digunakan sebagai landasan penelitian dan berperan dalam pengumpulan informasi secara lengkap untuk memecahkan suatu masalah. Landasan teori dapat berasal dari buku-buku atau referensi-referensi lain yang berhubungan dengan penelitian. Pada tahapan ini, literatur yang digunakan adalah analisis studi kelayakan yang terdiri dari aspek marketing, aspek teknis dan aspek finansial.

6. Analisis Data

Tahao ini dilakukan pengolahan data mengenai pendapat responden untuk melihat aspek marketing yang nantinya akan menjadi pasar bagi produk yang akan dibuat. Selanjutnya analisa aspek teknis untuk melihat ketersediaan teknologi yang tersedia, dan aspek finansial yang akan menentukan laba atau rugi dari produk yang akan dibuat yang menjadi dasar layak atau tidaknya bisnis ini untuk dijalankan.

7. Kesimpulan

Pada hal ini berisi beberapa kesimpulan terhadap penulisan analisis kelayakan produk alat bantu mencuci ini. Selain itu juga diberikan saran yang dapat dilakukan guna melakukan improvement yang dapat dilakukan sehingga mampu menambah nilai kelayakan produk. 


\section{HASIL DAN PEMBAHASAN \\ Aspek Marketing}

Pada aspek marketing ini akan dibahas mengenai analisis proyeksi permintaan yang akan menetukan jumlah produksi yang harus dibuat dan dijual, Selain itu juga akan dibahas strategi bauran pemasaran. Dapat diketahui pada tabel 1 tentang pertumbuhan indeks produksi bulanan industri besar dan sedang terus mengalami peningkatan. Hal ini menjadi indikasi bahwa prospek industri di Indonesia terus mengalami peningkatan. Iklim bisnis yang terus meningkat ini menandakan bahwa potensi keberhasilan usaha untuk diterima dimasyarakat cukup baik.

Tabel 1. Pertumbuhan Indeks Produksi Bulanan Industri Besar dan Sedang

\begin{tabular}{rrcrr}
\hline Tahun & \% Peningkatan & Tahun & \% Peningkatan \\
\hline 2010 & 1,43 & 2013 & 6,01 \\
2011 & 4,10 & 2014 & 4,76 \\
2012 & 4,12 & 2015 & 4,57 \\
\hline
\end{tabular}

Selain itu juga dikumpulkan data penjualan mesin cuci yang akan dijadikan indikasi kebutuhan masyarakat akan alat bantu mencuci dan didapatkan peningkatan sebesar $20 \%$ per tahun yang diambil dari data penjualan mesin cuci Sharp. Namun tingkat kepuasan konsumen akan kinerja mesin cuci masih rendah yang didapat dari hasil survei yang telah dilakukan sebelumnya. Selain itu berdasarkan observasi juga didapatkan masih banyak masyarakat yang belum memiliki mesin cuci dengan alasan biaya dan tingkat kebersihan yang kurang. Berdasarkan data dan informasi akan terus meningkatnya permintaan pasar akan mesin cuci yang tidak diimbangi dengan perbaikan sistem pencucian, maka diharapkan kehadiran produk alat bantu clean washing mc mampu memberikan inovasi pencucian yang lebih baik dengan harga lebih terjangkau sehingga mampu memenuhi kebutuhan masyarakat sebagai konsumen.

Dalam menetapkan proyeksi perintaaan berikut asumsi-asumsi dan nilai target yang digunakan untuk menganalisis permintaan: a). Diasumsikan target pasar utama adalah keluarga yang tinggal di provinsi Jawa Tengah dan Yogyakarta.

b). Diasumsikan pasar utama adalah keluarga kelas menegah dengan data dan klasifikasi kelas yang dilakukan oleh Boston Consulting Group (BCG)

c). Ditargetkan penjualan marketing mampu mencapai $1 \%$ dari potensi pasar yang ada.

Didefinisikan kelas menengah dari sumber BCG adalah mereka yang melakukan pengeluaran bulanan sebesar Rp.1.500.000 hingga Rp.3.000.000 tiap bulan. Berdasarkan klasifikasi kelas masyarakat yang didapatkan dari besarnya biaya pengeluaran diketahui kelas menengah di Indonesia sebesar 40,15 \%. Dengan pencarian data dan asumsi yang telah dibuat dilakukan perhitungan target penjualan tiap bulan seperti Persamaan 1 di bawah ini dan rincian perhitungan sesuai dengan Tabel 2 dan ditetapkan total target produksi sebesar 25 unit per hari.

$$
\begin{aligned}
\text { Penjualan }= & \text { Jml Keluarga Target Pasar } \times \\
& \% \text { Penduduk Kelas Menengah } \times \\
& \text { Target Penjualan }
\end{aligned}
$$

Untuk memberikan informasi mengenai produk yang akan ditawarkan secara menarik dan lugas maka diperlukan strategi pemasaran marketing mix. Pada marketing mix ini akan diberika informasi 4 varabel yang merupakan inti dari sebuah sistem pemasaran [1];

a. Produk (Product)

Produk yang ditawarkan adalah sebuah alat bantu mencuci dengan nama "clean washing $m c$ ”. Produk ini dikembangkan untuk melakukan perbaikan dari kekurangan metode pencucian dengan tangan dan dengan mesin cuci. Alat bantu ini mampu mencuci baju sebanyak 4-6 pakaian sekaligus tanpa tangan kontak dengan air detergen secara langsung, selain itu dengan hasil percobaan yang dilakukan memiliki kadar tingkat kebersihan baik.

b. Harga (Price)

Harga yang ditawarkan setelah melakukan perhitungan mengenai biaya variable cost, 
Tabel 2. Tabel Perhitungan Proyeksi Permintaan

\begin{tabular}{cccccc}
\hline Provinsi & $\begin{array}{c}\text { Jumlah Rumah } \\
\text { Tangga }\end{array}$ & $\begin{array}{c}\text { Masyarakat } \\
\text { Kls Menengah } \\
(\%)\end{array}$ & $\begin{array}{c}\text { Total Potensial } \\
\text { Pasar }\end{array}$ & $\begin{array}{c}\text { Target } \\
\text { marketing per } \\
\text { Tahun }(1 \%)\end{array}$ & $\begin{array}{c}\text { Target } \\
\text { marketing } \\
\text { per Bulan }\end{array}$ \\
\hline $\begin{array}{c}\text { Prov. Jawa Tengah } \\
\text { DIY }\end{array}$ & $\begin{array}{c}1.263 .918 \\
\text { 195.109 }\end{array}$ & 0,401 & 507.501 & 5.075 & 423 \\
& \multicolumn{7}{c}{78.342} & 783 & 65 \\
\hline & Total Target Penjualan per Bulan & & 488 \\
& Total Target Penjualan per Hari Kerja & \\
\hline
\end{tabular}

fix cost, nilai pay back period dan NPV. Selain itu berdasar pertimbangan Segmentasi pasar yang dituju, maka ditawarkan produk ini akan dijual seharga Rp. 550.000

c. Promosi (Promotion)

Untuk melakukan pengenalan produk agar produk dikenal masyarakat luas sebagai pasar utama, maka dilaukan promosi melalui beberapa cara: untuk menekan biaya pengeluaran maka promosi produk dilakukan melalui media sosial seperti Lazada, Bukalapak, OLX dsb serta menyebarkan brosur dan iklan di koran atau majalah untuk keluarga.

d. Tempat dan Distribusi (Place).

Berdasarkan perhitungan kebutuhan luas area produksi didapatkan luas area yang dibutuhkan seluas $367 \mathrm{~m}^{2}$. Dari luas tersebut dicari lahan produksi strategis yang sesuai segmentasi pasar yang akan dituju. Didapatkan sebuah pabrik di daerah Ginuk, Semarang - Jawa Tengah dengan luas bangunan $700 \mathrm{~m}^{2}$ yang mampu menampung mesin dan aktifitas produksi. Sedangkan untuk distribusi produk ditargetkan penjualan pada provinsi Jawa Tengah dan DIY.

\section{Aspek Teknik}

Selanjutnya adalah menentukan rancangan produk sesuai dengan yang diinginkan oleh konsumen. Secara garis besar urutan aliran proses analisis teknik seperti Gambar 1. Rancangan produk mengikuti langkah-langkah perancangan produk [2].

\section{Concept Development}

Untuk mengenalkan produk kepada konsumen dan memberikan informasi secara singkat tentang produk yang akan dibuat maka dirangkum sebuah tabel yang akan menerangkan tujuan dan gambaran produk yaitu Tabel 3.

Setelah pengenalan produk yang menggambarkan tujuan pembuatan produk, lalu langkah selanjutnya adalah melakukan analisis kebutuhan konsumen yang terangkum pada tabel customer needed seperti Tabel 4. Pada tabel tersebut akan dilakukan analisis kebutuhan konsumen yang disertai dengan bobot tingkat kepentingannya. Selanjutnya dilakukan analisis faktor-faktor nilai matrik dari produk yang akan dikembangkan.

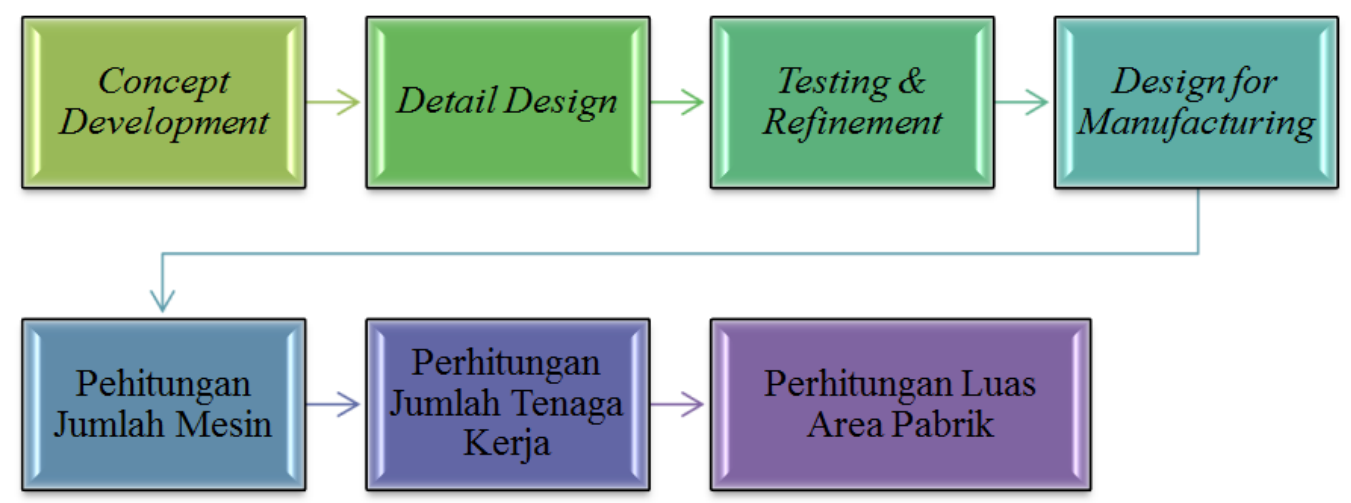

Gambar 1. Flow Proses Perhitungan Aspek Teknis 
Tabel 3. Mission Statement

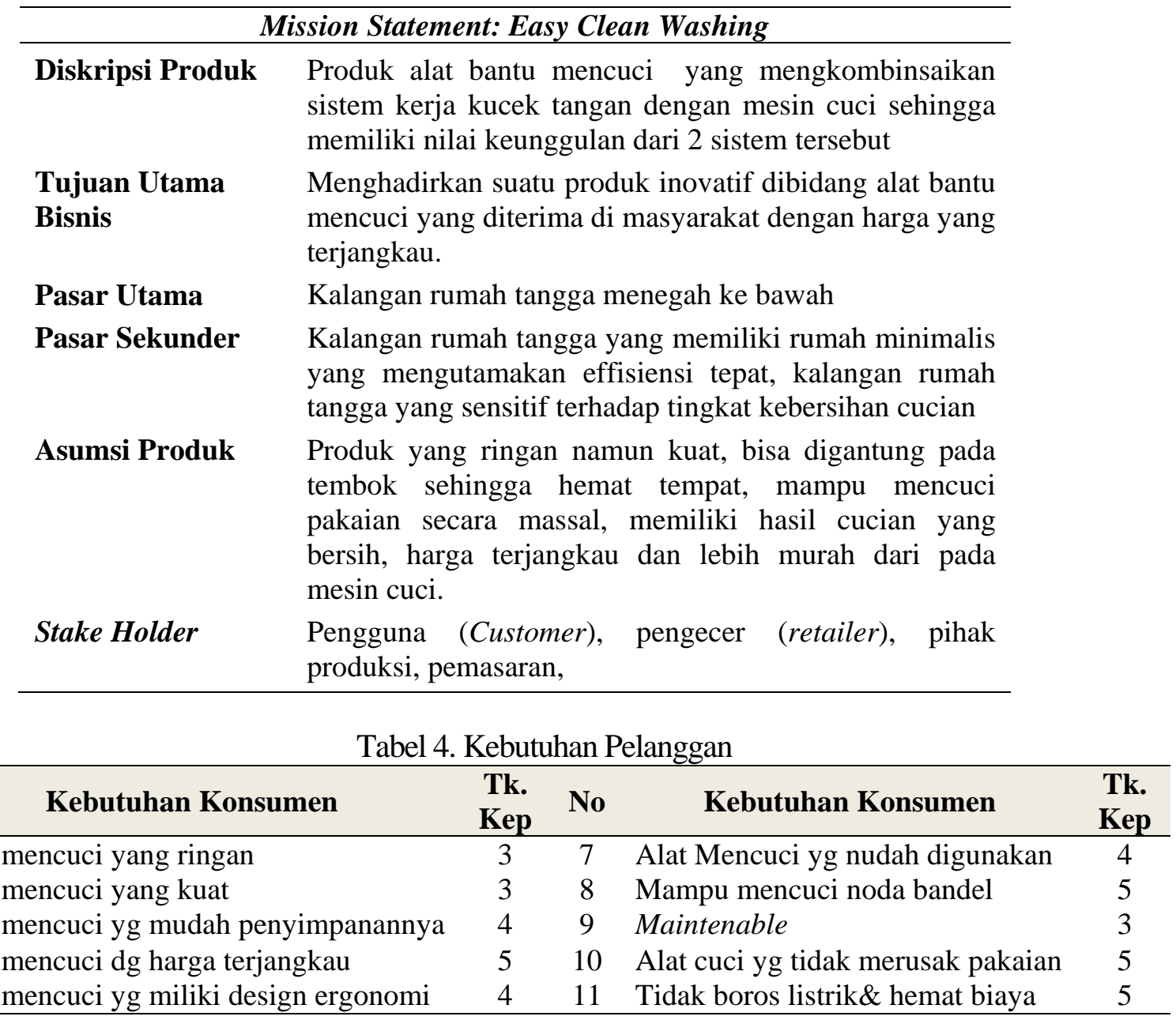

Tabel 5. Nilai Metric

\begin{tabular}{ccccc}
\hline No & Need & Metrics & Importance & Unit \\
\hline 1 & $1,2,3,4$ & Material & 3 & Subject \\
2 & 4 & Ukuran Produk & 4 & $\mathrm{~cm}$ \\
3 & 1,4 & Massa Produk & 4 & Kg \\
4 & $1,2,4,6,7,9,10$ & Desain & 4 & Subject \\
5 & 2, & Ketahanan produk & 4 & Tahun \\
6 & 8,10 & Kemampuan Produk & 5 & Subject \\
7 & 5,11 & Biaya pemakaian dan & 5 & Rp. \\
& pembelian & & \\
\hline
\end{tabular}

Pada Tabel 5 dianalisis hubungan antara customer needed dengan nilai matrik yang akan dibentuk pada rancangan produk disertai dengan tingkat kepentingannya. Korelasi antara kebutuhan konsumen dengan nilai metrik yang akan dikembangkan pada rancangan produk dapat dilihat pada Tabel 6.

Selanjutnya dilakukan pembuatan target dari nilai apa saja yang akan dicapai pada pembuatan rancangan produk yang nantinya akan dibuat seperti pada Tabel 7. Dari Tabel 7, dikembangkanlah ide dan dilakukan percobaan untuk mendapatkan konsep sistem kerja terbaik. Langkah-langkah dalam melakukan percobaan dalam menentukan sistem kerja yang akan digunakan adalah seperti pada deskripsi Gambar 2. 
Tabel 6. Need-Matrix

\begin{tabular}{|c|c|c|c|c|c|c|c|c|}
\hline No & Kebutuhan-Metrik & & 递 & 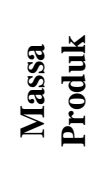 & 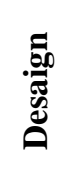 & 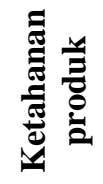 & 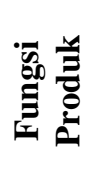 & 胥荀 \\
\hline 1 & Alat mencuci yang ringan & $\mathbf{O}$ & & $\mathrm{O}$ & $\mathbf{O}$ & & & \\
\hline 2 & Alat mencuci yang kuat & $\mathbf{O}$ & & & $\mathbf{O}$ & $\mathbf{O}$ & & \\
\hline 3 & Alat mencuci yang tahan karat & $\mathbf{O}$ & & & & & & \\
\hline 4 & mudah penyimpanannya & $\mathbf{O}$ & $\mathbf{O}$ & $\mathbf{O}$ & $\mathbf{O}$ & & & \\
\hline 5 & Alat mencuci dengan harga terjangkau & & & & & & & $\mathbf{O}$ \\
\hline 6 & design ergonomi & & & & $\mathbf{O}$ & & & \\
\hline 7 & Alat Mencuci yang Mudah digunakan & & & & $\mathbf{O}$ & & & \\
\hline 8 & Mampu mencuci noda bandel & & & & & & $\mathbf{O}$ & \\
\hline 9 & Maintenable & & & & $\mathbf{O}$ & & & \\
\hline 10 & Alat cuci yang tidak merusak pakaian & & & & $\mathbf{O}$ & & $\mathbf{O}$ & \\
\hline 11 & Tidak boros listrik dan hemat biaya & & & & & & & $\mathbf{O}$ \\
\hline
\end{tabular}

Tabel 7. Tabel Nilai Target

\begin{tabular}{|c|c|c|c|c|c|}
\hline No & Need & Metrics & $\begin{array}{c}\text { Impor } \\
\text { tance }\end{array}$ & Unit & Nilai Target \\
\hline 1 & $1,2,3,4$ & Material & 3 & subyek & $\begin{array}{l}\text { Untuk menghasilkan material yang ringan, kuat, } \\
\text { anti karat dan mudah dipindahkan maka } \\
\text { dilakukan perancangan dengan kombinasi } \\
\text { material plastik dan besi dengan pelapisan cat } \\
\text { anti karat }\end{array}$ \\
\hline 2 & 4 & $\begin{array}{l}\text { Ukuran } \\
\text { Produk }\end{array}$ & 4 & $\mathrm{~cm}$ & $\begin{array}{l}\text { Ditetapkan ukuran alat bantu selebar } 60 \text { × } 40 \mathrm{~cm} \\
\text { agar kapasitas pencucian \& kemudahan } \\
\text { penyimpanan seimbang }\end{array}$ \\
\hline 3 & 1,4 & $\begin{array}{l}\text { Massa } \\
\text { Produk }\end{array}$ & 3 & Kg & $\begin{array}{l}\text { untuk mendapatkan massa produk yang ringan } \\
\text { dan mudah disimpan / dipindahkan maka } \\
\text { ditetapkan rancangan design dengan target max. } \\
\text { berat } 3 \mathrm{~kg} \text {. }\end{array}$ \\
\hline 4 & $\begin{array}{c}1,2,4,6, \\
7,9,10\end{array}$ & Desain & 4 & subyek & $\begin{array}{l}\text { Posisi handel penggerak terjangkau oleh tangan } \\
\text { nilai ergonomi dan tinggi alat bantu sejajar } \\
\text { dengan jangkauan tangan saat duduk } \\
\text { dipasang spring penekan pada spon penggosok } \\
\text { bawah agar tekanan pada baju dapat disesuaikan } \\
\text { menggunakan urethane pada support untuk } \\
\text { meredam getaran, }\end{array}$ \\
\hline 5 & 2 & $\begin{array}{c}\text { Ketahanan } \\
\text { produk }\end{array}$ & 4 & Nowton & $\begin{array}{l}\text { menggunakan rangka pipa besi pada rangka } \\
\text { utama agar kuat menahan beban tumpuan, spon } \\
\text { penggosok mudah diganti jika terjadi kerusakan }\end{array}$ \\
\hline 6 & 8,10 & $\begin{array}{c}\text { Kemampuan } \\
\text { Produk }\end{array}$ & 5 & Subjek & $\begin{array}{l}\text { sistem kerja mengadopsi gerakan mencuci } \\
\text { tangan agar hasil cucian yang dihasilkan lebih } \\
\text { baik dari sistem mesin cuci. }\end{array}$ \\
\hline 7 & 5,11 & $\begin{array}{l}\text { Biaya } \\
\text { pemakaian } \\
\text { dan } \\
\text { pembelian }\end{array}$ & 5 & Rp. & $\begin{array}{l}\text { Digunakan material plastik pada komponen yang } \\
\text { tidak terlalu menerima beban agar biaya murah, } \\
\text { Sistem penggerak dilakukan secara manual agar } \\
\text { tidak diperlukan biaya listrik dan harga produksi } \\
\text { murah. }\end{array}$ \\
\hline
\end{tabular}




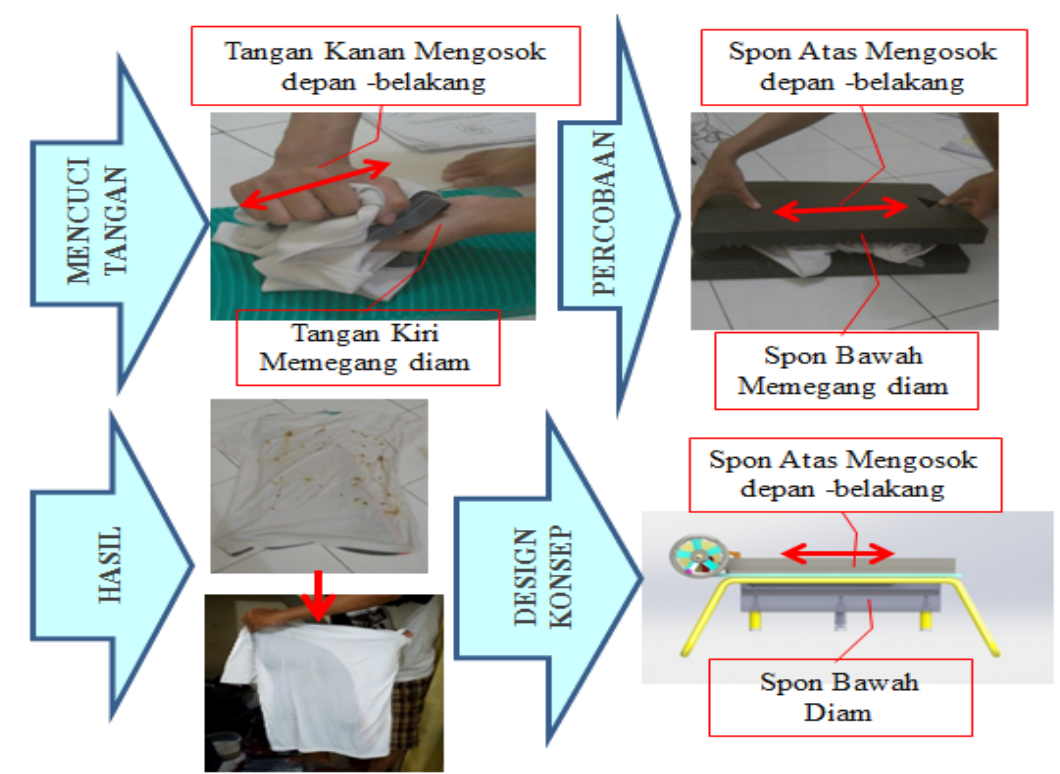

Gambar 2. Flow Proses Menentukan Konsep Kerja Rancangan Produk

A

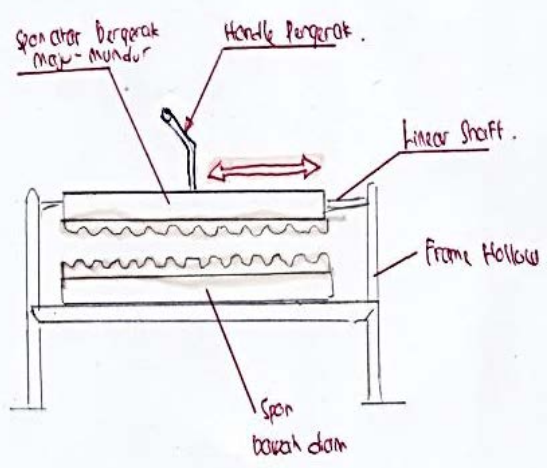

B

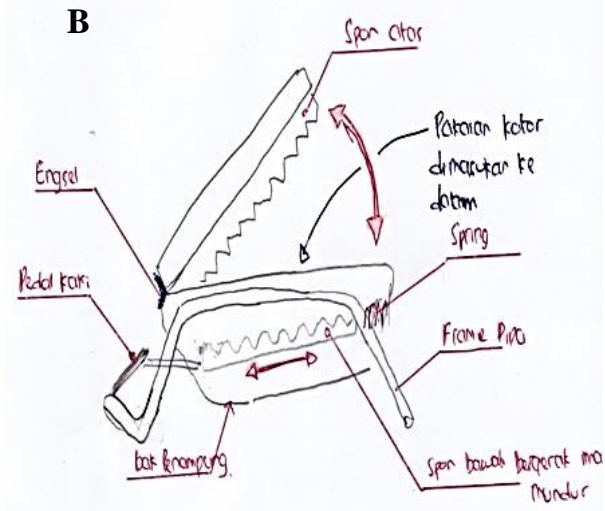

Gambar 3. Konsep rancangan A (Kiri) dan konsep rancangan B (Kanan)

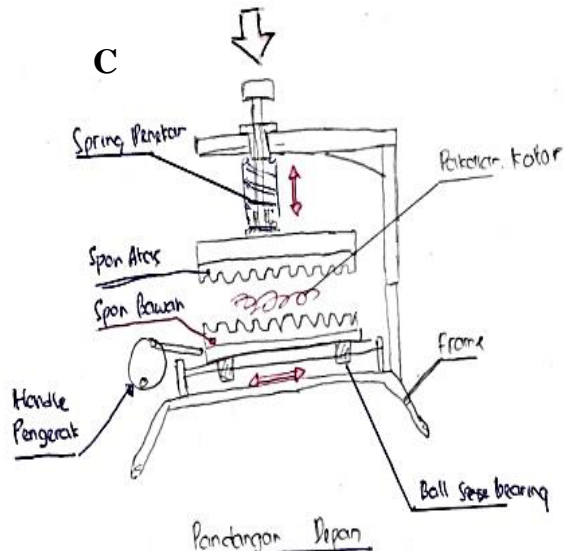

Gambar 4. Konsep Rancangan C (Kiri) dan Konsep Rancangan D (Kanan)
Dari 4 rancangan konsep tesebut lalu dilakukan analisis dan diambil 2 konsep rancangan terbaik melalui proses screening. Dari proses screening didapatkan rancangan terbaik adalah konsep $\mathrm{C}$ dan $\mathrm{D}$. dari 2 konsep

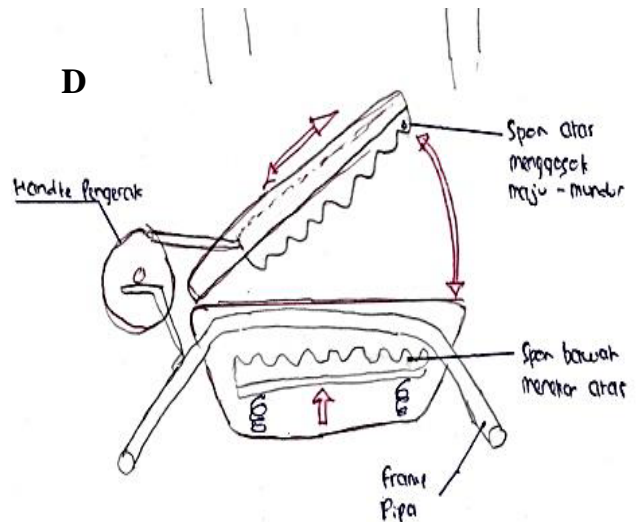

terbaik yang dipilih tersebut lalu dilakukan penilaian (Scoring metric) dengan memberikan nilai pada masing masing kriteria matrik sesuai pada Tabel 8. 
Detail Rancangan

Setelah ditetapkan konsep design yang terbaik berdasarkan kriteria matix yang akan dibentuk, langkah berikutnya adalah menyempurnakan konsep perancangan yang telah lengkap disertai ukuran, dimensi, jenis material yang akan digunakan, datum, toleransi pengerjaan dan material standar yang dibutuhkan. Dengan bantuan software design pada komputer didapatkan hasil detail design seperti yang terlihat pada Gambar 5.

Tabel 8. Scoring Matric

\begin{tabular}{|c|c|c|c|c|c|c|}
\hline \multirow{3}{*}{ No. } & \multirow{3}{*}{ Kriteria } & \multirow{3}{*}{ Bobot } & \multicolumn{4}{|c|}{ Rancangan Konsep Terpilih } \\
\hline & & & \multicolumn{2}{|c|}{ C } & \multicolumn{2}{|c|}{$\mathrm{D}$} \\
\hline & & & Rating & Nilai & Rating & Nilai \\
\hline 1 & Ringan & $60 \%$ & 3 & 1.8 & 3 & 1.8 \\
\hline 2 & Kuat & $60 \%$ & 3 & 1.8 & 3 & 1.8 \\
\hline 3 & Mudah disimpan & $80 \%$ & 4 & 3.2 & 4 & 3.2 \\
\hline 4 & Tidak Mudah Berkarat & $100 \%$ & 2 & 2 & 2 & 2 \\
\hline 5 & Mudah digunakan & $100 \%$ & 4 & 4 & 4 & 4 \\
\hline 6 & Maintenabel & $60 \%$ & 2 & 1.2 & 4 & 2.4 \\
\hline 7 & kapasitas baju & $60 \%$ & 4 & 2.4 & 4 & 2.4 \\
\hline 8 & Ergonomic & $100 \%$ & 5 & 5 & 4 & 4 \\
\hline & Nilai Total & & & 21.4 & & 21.6 \\
\hline & Lanjut? & & & Tidak & & Ya \\
\hline
\end{tabular}

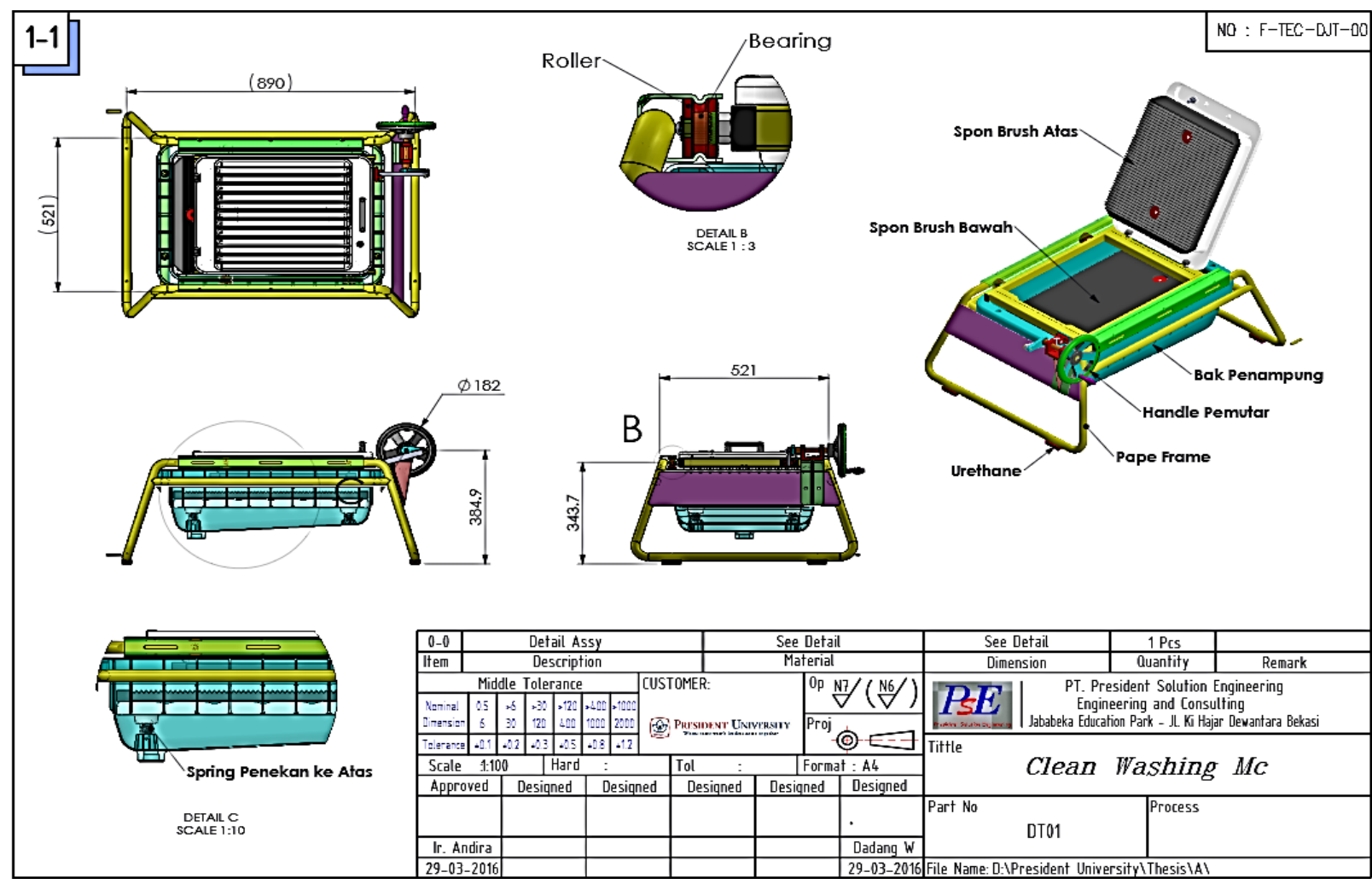

Gambar 5. Engineering Drawing Detail Rancangan.

\section{Design for Manufacturing}

Design manufacturing merupakan tahapan untuk melakukan analisis bagaimana sebuah sistem manufacturing tersebut akan berlangsung. Untuk menentukan proses manufacturing maka diperlukan beberapa perhitungan. Pada produk rancangan ini dilakukan perhitungan mengenai jumlah dan dan spesifikasi komponen penyusun produk yang nanti juga akan digunakan untuk perhitungan biaya material. 
Setelah melakukan pendataan komponen penyusun lalu selanjutnya dilakukan analisis proses yang terangkum pada diagram Operation Process Chart yang menggambarkan proses manufacturing dari material mentah hingga proses perakitan produk jadi. Setelah semua proses berhasil teridentifikasi lalu selanjutnya dilakukan perhitungan jumlah mesin yang dibutuhkan berdasar operasi proses yang diperlukan [3].

Untuk contoh perhitungan jumlah mesin yang dibutuhkan dapat dlihat pada perhitungan berikut.

Perhitungan kebutuhan mesin Gerinda Potong pada operasi proses 01 Jumlah produksi/hari adalah 25 unit, jumlah jam kerja 480 menit/hari dan efisiensi mesin $70 \%$ dan Cycle Time sebesar 2 menit/unit.

$$
\begin{aligned}
\text { Jumlah Mesin } & =\frac{\text { Cycle Time } \mathrm{x} \text { Jumlah Produksi }}{\text { Jam operasi } \times \text { Efisiensi Mesin }}(2) \\
\text { Jumlah Mesin } & =\frac{2 \text { menit } \times 25 \text { unit per hari } \times 1 \text { pcs }}{480 \text { menit } \times 70 \%} \\
& =0,1488 \text { mesin }
\end{aligned}
$$

Dari cara perhitungan di atas, lalu dilanjutkan hingga proses hingga ke-82 dan dilakukan penjumlahan pada mesin yang memiliki jenis yang sama. Dari hasil penjumlahan tersebut lalu dirangkum dan diapatkan hasil jumlah mesin yang dibutuhkan Untuk menghemat biaya tenaga kerja, maka digunakan strategi dengan menempatkan 1 atau beberapa operator ke beberapa jenis pekerjaan yang didasarkan pada nilai utilitas mesin yang telah dihitung. Pada Tabel 9 dapat dilihat nilai total dari kebutuhan jumlah masing-masing mesin. Selanjutnya dilakukan penjumlahan untuk menentukan klasifikasi jenis pekerjaan dan jumlah dari tenaga kerja langsung.

Sedangkan ditetapkan tenaga kerja tidak langsung berdasar asumsi dan analisis kebutuhan untuk menjalankan proses manufacturing didapatkan kebutuhan tenaga kerja tidak langsung adalah: kepala produksi, engineering, PPIC, dan marketing

Selain itu diperlukan juga perhitungan luas area produksi yang akan menentukan spesifikasi dari pabrik yang diperlukan yang nantinya akan berpengaruh pada harga pabrik yang harus dibeli dan masuk kedalam aliran biaya tetap. Untuk perhitungan luas area didapatkan hasil Total kebutuhan Luas Arera sebesar $367 \mathrm{~m}^{2}$ termasuk Gudang, lantai produksi dan fasilitas pendukung lainnya.

\section{Aspek Finansial}

Dalam menentukan analisis aspek finansial dilakukan beberapa tahapan. Pertama adalah melakukan perhitungan biaya manufacturing yang terdiri dari biaya variable cost dan biaya fix cost. Setelah didapatkan biaya fixed cost dan variable cost maka dapat dilakukan perhitungan besarnya contribusi margin, dan dapat dilakukan perhitungan CPV (Cost-Volume-Profit). Dari perhitungan CPV tersebut bisa diketahui besarnya pay back period dan net present value yang akan menjadikan dasar penentuan feasible atau tidak produk bisnis ini [4].

Setelah dilakukan perhitungan dari biaya mesin yang dibutuhkan, harga pabrik bangunan yang diperlukan hingga biaya variable cost yang lain didapatkan hasil perhitungan seperti pada Tabel 10. Asumsi-asumsi yang digunakan dalam perhitungan dapat dilihat pada Tabel 11.

Tabel 9. Perhitungan Jumlah Mesin dan Tenaga Kerja Langsung

\begin{tabular}{ccccc}
\hline No. & Operator & Utilitas & Total & Job Mesin \\
\hline 1 & Section Bubut & 2,786458333 & 3 & No. 13 \\
2 & Section Cutting & 2,735408399 & 3 & No. 1,4,10,14,17,18,19 \\
3 & Section Milling & 2,834201389 & 3 & No.12 \\
4 & Sec. Stamping & 1,179356812 & 2 & No. 2,5,8,9 \\
5 & Sec. Welding & 2,863963294 & 3 & No. 3,6,7,16 \\
6 & Sec. Spary Gun & 1,93452381 & 2 & No. 11 \\
7 & Sec. Assembly \& Inspect & 0,950376157 & 1 & No. 15,20 \\
\hline \multicolumn{7}{r}{} \\
\hline
\end{tabular}


Perhitungan besarnya nilai depresiasi yang nantinya akan mempengaruhi besarnya pajak. Dilakukan juga perhitungan besarnya nilai pendapatan yang didapatkan dari harga jual dikalikan total penjualan. Dari hasil tersebut dilakukan perhitungan besarnya nilai NPV dan IRR seperti pada Tabel 12.

Tabel 10. Hasil Perhitungan Biaya Variable Cost dan Fixed Cost

\begin{tabular}{|c|c|c|c|c|}
\hline & Variable & Total Biaya & Biaya / unit & TOTAL (Rp.) \\
\hline \multirow{4}{*}{ 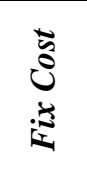 } & Cost of Machine \& Tools & $2,006,204,400$ & $\mathrm{n} / \mathrm{a}$ & \multirow{4}{*}{ 3.306.204.400 } \\
\hline & Cost of Factory & $1,200,000,000$ & $\mathrm{n} / \mathrm{a}$ & \\
\hline & Biaya Marketing / 10 Tahun & $50,000,000$ & $\mathrm{n} / \mathrm{a}$ & \\
\hline & Biaya Tidak Terduga & $50,000,000$ & $\mathrm{n} / \mathrm{a}$ & \\
\hline \multirow{3}{*}{$\frac{0}{\sqrt[3]{*}}$} & Biaya Listrik / hari & 770,843 & 30,834 & \multirow{3}{*}{421.053} \\
\hline & Direct Material / unit & $\mathrm{n} / \mathrm{a}$ & 334,935 & \\
\hline & Direct Labour / day & $1,382,100$ & 55,284 & \\
\hline
\end{tabular}

Tabel 11. Asumsi Asumsi Perhitungan

\begin{tabular}{lc}
\hline Harga Jual Produk & Rp. 550,000 \\
\hline Produksi / hari (unit) & 25 \\
Pertumbuhan Penjualan & $8 \%$ \\
Hari kerja per bulan & 20 \\
Inflasi per tahun & $9 \%$ \\
Pajak & $10 \%$ \\
Umur Ekonomis (Tahun) & 10 \\
Nilai Sisa & $20 \%$ Harga Mesin \\
\hline
\end{tabular}

Tabel 12. Perhitungan Nilai NPV dan IRR

\begin{tabular}{ccccc}
\hline Tahun & $\begin{array}{c}\text { In Flow } \\
\text { (Setelah Pajak) }\end{array}$ & $\begin{array}{c}\text { Out Flow } \\
\text { Investasi }\end{array}$ & Penyusutan & Proceed (Rp.) \\
\hline Tahun 0 & 0,0 & $3.306,2$ & 0 & $(3,306,2)$ \\
Tahun 1 & 457,4 & & 265,5 & 723 \\
Tahun 2 & 501,7 & 265,5 & 767 \\
Tahun 3 & 548,6 & 265,5 & 814 \\
Tahun 4 & 598,2 & 265,5 & 864 \\
Tahun 5 & 650,7 & 265,5 & 916 \\
Tahun 6 & 706,1 & 265,5 & 972 \\
Tahun 7 & 764,6 & 265,5 & 1.030 \\
Tahun 8 & 826,4 & 265,5 & 1.092 \\
\hline \multicolumn{5}{c}{ NPV } \\
\hline
\end{tabular}

Dari informasi total pengeluaran dan biaya fixed cost didapatkan lamanya pengembalian modal selama 4 Tahun +1 Bulan + 17 Hari Kerja.

\section{KESIMPULAN}

Dari aspek marketing dapat dilihat potensial pasar yang cukup besar yang ditandai dengan tingginya permintaan akan alat bantu mencucuci sedangkan kepuasan masyarakat sebagai konsumen akan kinerja mesin cuci masih rendah. Selain itu potensi perkembangan industri yang terus meningkat yang dapat dijadikan indikator peluang dalam menjalankan usaha. Dari aspek teknis telah dilakukan pengembangan rancangan produk yang didasarkan akan kebutuhan konsumen dengan analisis need metrix. Selain itu juga dilakukan uji coba simulasi kerja, perhitungan ketersediaan teknologi, jumlah mesin, tenaga kerja, dan parhitungan luas area produksi. Dari aspek teknis lalu dilakukan perhitungan aspek 
finansial dengan memperhitungkan diaya variable cost dan fixed cost. Didapatkan dari perhitungan aspek finansial lama pengembalian modal selama 4 tahun, 1 bulan dan 17 hari kerja, nilai NPV 1.941.000.000 dan besarnya IRR sebesar $20 \%$.

\section{DAFTAR PUSTAKA}

[1] Kotler, Philip. (2000) Manajemen Pemasaran di Indonesia: Analisis, Perencanaan, implementasi, dan Pengendalian. Edisi 1. Terjemahan A.B Susanto. Jakarta: Salemba Empat.
[2] Ulrich, T Karl. (2012). Product Design and Development, $5^{\text {th }}$ Edition, McGrawHill

[3] Heragu, S. (1997), Facilities Design. Boston: PWS Publishing Company.

[4] Newnan, Donald G. (1990) Engineering Economic Analysis, Edisi 3, Binarupa Aksara. 